\title{
Elastic and Deformation Characteristics of MSWI Bottom Ash for Road Construction
}

\author{
Van Tien Phan \\ Faculty of Construction \\ Vinh University \\ Vinh City, Vietnam \\ vantienkxd@vinhuni.edu.vn
}

\author{
Thi Thu Hien Nguyen \\ Faculty of Construction \\ Vinh University \\ Vinh City, Vietnam \\ thuhien.tvna@gmail.com
}

\begin{abstract}
Bottom ash from Municipal Solid Waste Incineration (MSWI) is a typical granular material resulting from the incineration of domestic waste. It is mainly used in road engineering substituting traditional natural aggregates. As the characterization of the mechanical behavior is essential, the work presented in this paper pursues the study of the elastic and deformation characteristics of bottom ash, in particular Young's modulus and Poisson's ratio. From the consolidated-drained triaxial test data, it was possible to extract fundamental material parameters about the samples, including their Young's modulus E0.2 and E50, its Poisson's ratio $v$, and its maximum deviatoric stress peak. These parameters were then used in computer models to predict how the bottom ash will behave in a largerscale engineering application. Furthermore, the mechanical behavior of bottom ash related to road construction's loading condition, especially the secant modulus, was detailed.
\end{abstract}

Keywords-bottom ash; municipal solid waste; incineration; triaxial test

\section{INTRODUCTION}

Waste management has become a major preoccupation of federal and state agencies. It consists mainly of construction waste, fly ash and bottom ash [1-11]. Bottom ash from Municipal Solid Waste Incineration (MSWI) is the solid residue from the combustion of municipal waste. It consists mainly of silica and alumina, limestone, lime, water, salt, heavy metals and unburned wastes [6, 12-14]. They are granular materials, potentially recoverable for engineering works, especially in road construction [1, 12-18]. In France, about 3 million tons of bottom ash are produced annually $[2,19]$. In recent years, bottom ash is either used in road engineering $(84 \%)$ or is disposed in non-hazardous waste facilities $(16 \%)$ [17]. In France, after treatment, bottom ash is classified into three categories according to its physical and chemical characteristics as defined in [17]. The use of bottom ash is highly regulated: its use must be safe for the environment, must meet standards, and requires a thorough knowledge of the material. This study aims to study the elastic and deformation characteristics of bottom ash. The triaxial testing method is described, and then the basic parameters of bottom ash (elastic and volumetric parameters) are calculated. These results are discussed by analyzing and simulating the corresponding formula of Schanz and Vermeer [20].

\section{MATERIALS AND METHODS}

\section{A. Materials}

The studied bottom ash came from a platform of waste recycling based in Fretin, near Lille, owned by the PréFerNord Company. This bottom ash was taken from the factory, after having undergone a sorting (removal of ferrous elements, aluminum and heavy elements). It is a bottom ash type V1 or V2, which can be used in public works such as trench backfill or sub-layer of pavement, in place of finer materials such as sand or gravel.

\section{B. Triaxial test}

Two sets, A and B, of consolidated-drained triaxial tests were performed (Table I). The two porewater pressures $p_{w}$ corresponding to tests $\mathrm{A}$ and $\mathrm{B}$ are, respectively, $p_{w}=200 \mathrm{kPa}$ and $p_{w}=400 \mathrm{kPa}$. In both tests, the effective confining pressure varied from 100 to $400 \mathrm{kPa}$, corresponding to a total confining stress ranging from 300 to $600 \mathrm{kPa}$ for test A and 500 to $800 \mathrm{kPa}$ for test B. The principles of the tests are in accordance to the French standard NF P 94-074.

TABLE I. TRIAXIAL TEST CONDITIONS

\begin{tabular}{|c|c|c|c|}
\hline Tests & $\begin{array}{c}\text { Porewater } \\
\text { pressure } \\
\boldsymbol{p}_{\boldsymbol{w}}(\mathbf{k P a})\end{array}$ & $\begin{array}{c}\text { Confining } \\
\text { pressure } \\
\boldsymbol{\sigma}_{\mathbf{3}}(\mathbf{k P a})\end{array}$ & $\begin{array}{c}\text { Effective } \\
\text { confining pressure } \\
\boldsymbol{\sigma}_{\mathbf{3}}^{\prime} \mathbf{( k P a )}\end{array}$ \\
\hline A1 & 200 & 300 & 100 \\
\hline A2 & 200 & 400 & 200 \\
\hline A3 & 200 & 500 & 300 \\
\hline A4 & 200 & 600 & 400 \\
\hline B1 & 400 & 500 & 100 \\
\hline B2 & 400 & 600 & 200 \\
\hline B3 & 400 & 700 & 300 \\
\hline B4 & 400 & 800 & 400 \\
\hline
\end{tabular}

The triaxial test is a standardized test. A cylindrical sample of the material is placed in a membrane and subjected to a confining stress $\sigma_{3}$ and an axial stress $\sigma_{l}$. The experimental methodology is described below.

\section{1) Saturation}

At first, bottom ash compact samples were made. For this, a water content of $12.5 \%$ (water content corresponding to the modified Proctor optimum determined by our framing) was 
poured in bottom ash. This mixture was compacted with the modified Proctor compactor set with European standard EN 13286-2 [21], what corresponds to filling the cylindrical mold Proctor (117.5mm height, $101.5 \mathrm{~mm}$ diameter) in 5 layers, each compacted by 25 strokes of modified Proctor in order to obtain a surface as flat as possible. Then, the sample was placed around two protective latex membranes with a striated plastic film between (Figure 1).
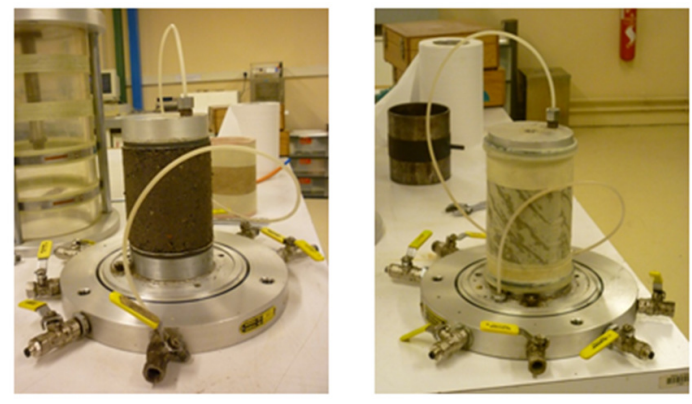

Fig. 1. Sample on its base, with and without protective membranes.

The tightness of this system was ensured with four rubber seals and then the sample was set up in the triaxial apparatus (Figure 2). Triaxial tests were conducted with fully saturated samples. The saturation was handmade. Sample degassing was performed by creating an updraft from bottom to top with two cruets: one was filled with water and was connected to the bottom of the sample, the other was empty and connected to the upper part of the sample, with a radial pressure of $\sigma_{3}=20 \mathrm{kPa}$. Saturation cycles were performed with those two cruets, until there were no more visible air bubbles, and a volume of $40 \mathrm{ml}$ of sample output was collected. This was followed by a saturation with two GDS which continued for 400min.

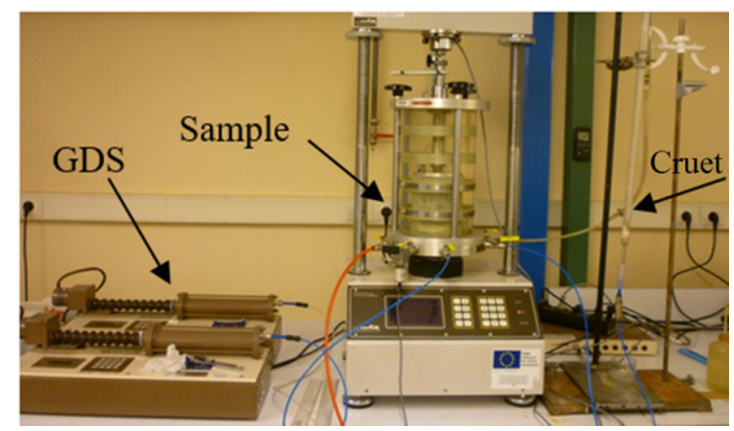

Fig. 2. Overview of the triaxial test.

That finished saturation was checked by calculating the Skempton coefficient $B=\Delta u / \Delta \sigma_{3}$. This coefficient is an indicator of advanced saturation. It has to be larger than 0.9 to indicate a successful saturation.

\section{2) Consolidation}

The consolidation step was then launched for $800 \mathrm{~min}$. It was performed with cell pressure $\sigma_{3}=400 \mathrm{kPa}$ ( or $\sigma_{3}=600 \mathrm{kPa}$ for test type B) and back pressure $u_{w}=200 \mathrm{kPa}$ (or $u_{w}=400 \mathrm{kPa}$ for test type B). The initial effective confining stress remains $p^{\prime}=200 \mathrm{kPa}$.

\section{3) Shear}

When consolidation was finished, the shearing of the samples started. Cell pressure was $400 \mathrm{kPa}$ and $600 \mathrm{kPa}$ and back pressure was $200 \mathrm{kPa}$ and $400 \mathrm{kPa}$ for test types A and $\mathrm{B}$ respectively and were kept constant during this step. An axial stress deviator was applied on the upper part of the sample until the axial strain reached $\varepsilon_{l}=14 \%$.

\section{Calculation of the Basic Parameters of Bottom Ash}

There are three elastic parameters: the initial Young's modulus $E_{0.2}$, the sequent stiffness $E_{50}$, and the maximum deviatoric stress $q_{\text {peak }}$. In addition, volume parameters such as the Poisson's ratio $v$ were determined. The determination of Young modulus value concerns the calculation of settlement [22]. When a value of Young modulus is quoted for civil engineering aggregates, it is usually the secant modulus that is specified [23]. The secant modulus $E$ is obtained from the initial slope of the deviator curve $\left(q, \varepsilon_{1}\right)$ at $0.2 \%$ of axial strain or at $50 \%$ of the maximum deviator stress as illustrated in Figure 3. This range $\left(E_{0.2}, E_{50}\right)$ is a common range of working stress in actual foundation problems. It depends on the case: either of $E_{0.2}$ or $E_{50}$ may be chosen, but in practice $E_{50}$ is often preferred $[1,24]$. Deviator stress is the difference between the axial and confining stresses in a triaxial test. Failure stress is the maximum deviator stress $q_{\text {peak }}$.

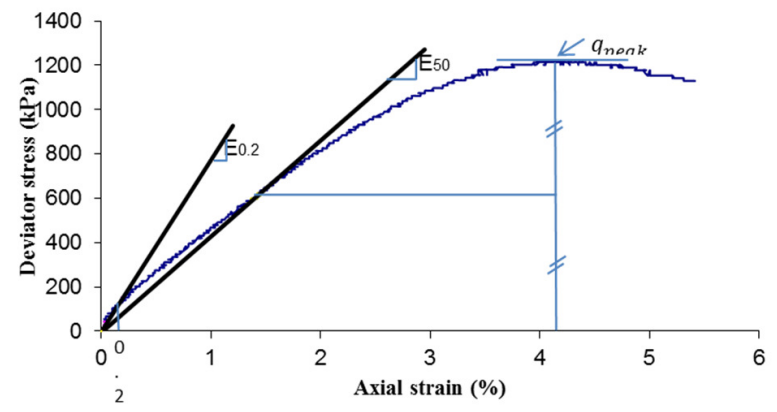

Fig. 3. Determination of secant moduli and maximum deviator stress.

The Poisson ratio $v$ is the ratio transverse strain to axial strain of a loaded specimen. It is obtained from the initial slope of the volumetric strain curve $\left(\varepsilon_{v}, \varepsilon_{1}\right)$ (Figure 4), using (1):

$$
v=\frac{1}{2}\left(\frac{d \varepsilon_{v}}{d \varepsilon_{1}}-1\right)
$$

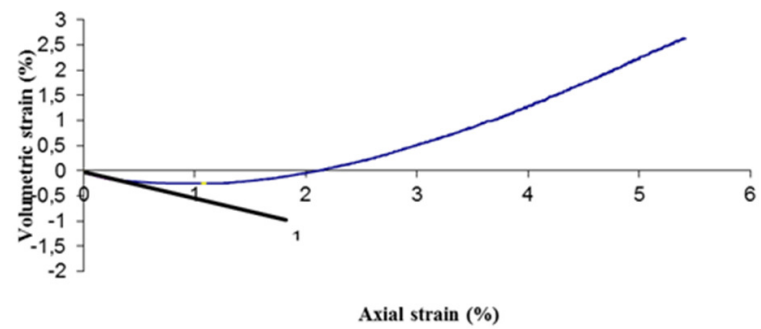

Fig. 4. Determination of Poisson's ratio. 


\section{Formula of Schanz and Vermeer}

The formula of Schanz and Vermeer [20] for dense and clean sand is:

$$
\frac{E_{50}}{p^{r e f}} \approx 500 \sqrt{\frac{\sigma_{3}^{\prime}}{p^{r e f}}}
$$

where $E_{50}$ is the secant modulus obtained from the initial slope of the deviator curve at $50 \%$ of the maximum deviator stress, $p^{r e f}=100 \mathrm{kPa}$, and ${\sigma_{3}}^{\prime}$ is the effective confining pressure.

\section{RESULTS AND DISCUSSION}

\section{A. Triaxial Test Curves}

The response for consolidated-drained triaxial tests is shown in Figures 5 and 6. On these Figures, the deviator stress $q=\left(\sigma_{1}-\sigma_{3}\right)$ and the volumetric strain $\varepsilon_{v}$ are plotted versus the axial strain $\varepsilon_{1}$. For both tests $\mathrm{A}$ and $\mathrm{B}$, the curves of the deviator stress evolution are quite similar in terms of trend and quantitative results (Figure 5). The first phase is almost linear up to $70 \%$ of the peak deviator stress $q_{\text {peak }}$ followed by the second non-linear phase up to the peak deviator stress. There is a final phase where the curves tend towards a level characterized by a residual deviator stress. In Figure 6 , the strain curves show an initial phase of contraction followed by a phase of dilatancy for large strains. For large strains without localization phenomenon, it can be assumed that all the curves tend towards a horizontal asymptote (critical). These responses indicate that the mechanical behavior of bottom ash is similar to that of dense sand $[3,15,25,26]$.

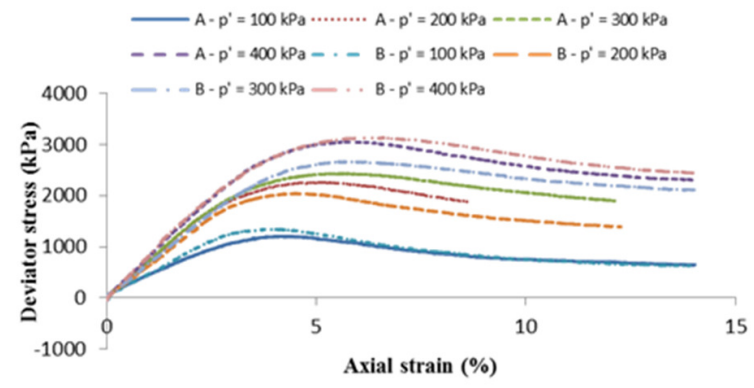

Fig. 5. Evolution of deviator stress in the triaxial tests.

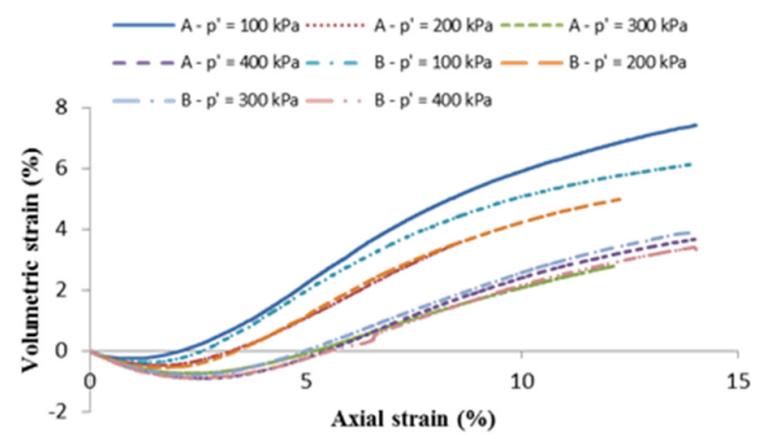

Fig. 6. Evolution of volumetric strain in the triaxial tests.

\section{B. Basic Parameters of Bottom Ash}

The obtained basic parameters of bottom ash are reported in Table II. The elastic behavior of the studied bottom ash is close to the elastic behavior of sand and gravel ( $E$ for sand: 50$80 \mathrm{MPa}$, for gravel: $100-200 \mathrm{MPa}$ ), which are typical materials used for constructions embankments, road bases, and sub-bases [16]. Values are similar to those of [4] for the bottom ash from the PréFerNord Company, however this bottom ash was obtained 3 years earlier. The obtained values of secant moduli indicate that bottom ash exhibits good resistance capacity to deformation. The difference between $E_{0.2}$ and $E_{50}$ indicates that the first phase of the deviator curve is nonlinear.

TABLE II. ELASTIC AND DEFORMATION CHARACTERISTICS

\begin{tabular}{|c|c|c|c|c|}
\hline Test & $\left(\boldsymbol{\sigma}_{\mathbf{1}}-\boldsymbol{\sigma}_{\mathbf{3}}\right)_{\max }(\mathbf{k P a})$ & $\boldsymbol{E}_{\mathbf{0 . 2}} \mathbf{( M P a )}$ & $\boldsymbol{E}_{\mathbf{5 0}} \mathbf{( M P a )}$ & $\boldsymbol{v}$ \\
\hline A1 & 1215 & 75.33 & 42.56 & 0.243 \\
\hline A2 & 2283 & 83.02 & 70.01 & 0.235 \\
\hline A3 & 2463 & 87.23 & 73.22 & 0.206 \\
\hline A4 & 3090 & 92.47 & 79.82 & 0.197 \\
\hline B1 & 1357 & 72.56 & 48.71 & 0.217 \\
\hline B2 & 2073 & 78.89 & 63.56 & 0.224 \\
\hline B3 & 2707 & 86.35 & 69.51 & 0.212 \\
\hline B4 & 3179 & 94.85 & 81.90 & 0.180 \\
\hline
\end{tabular}

Both secant moduli $E_{0.2}$ and $E_{50}$ increase with maximum deviator stress $q_{\text {peak }}$. The relationships between these parametersis nearly linear, expressed as:

$$
\begin{aligned}
& E_{0.2}=12.73 q_{\text {peak }}+55388(\mathrm{kPa}) \\
& E_{50}=18.81 q_{\text {peak }}+22985(\mathrm{kPa})
\end{aligned}
$$

On the other hand, the Poisson ratio (Table II) does not change much according to the effective confining pressure. The obtained Poisson ratios are similar to those of sand [27].

\section{Application of the Formula of Schanz and Vermeer}

Tables III-IV present the comparison between the secant modulus of this study and $[4,20]$. The errors between the obtained and predicted secant moduli are rather high, so the formula of Schanz and Vermeer is not applicable for bottom ash.

TABLE III. VALUES OF SECANT MODULUS $E_{50}(\mathrm{MPA})$

\begin{tabular}{|c|c|c|c|c|}
\hline $\boldsymbol{\sigma}_{3}{ }^{\prime}(\mathbf{k P a})$ & Tests A & Tests B & {$[\mathbf{2 0}]$} & {$[\mathbf{3 - 4}]$} \\
\hline 100 & 42.56 & 48.71 & 50 & 60 \\
\hline 200 & 70.01 & 63.56 & 70.71 & 69 \\
\hline 300 & 73.22 & 69.51 & 86.60 & 91 \\
\hline 400 & 79.82 & 81.90 & 100 & 136 \\
\hline
\end{tabular}

TABLE IV. ERRORS BETWEEN OBTAINED AND PREDICTED SECANT MODULUS VALUES

\begin{tabular}{|c|c|c|c|}
\hline $\boldsymbol{\sigma}_{3}{ }^{\prime}(\mathbf{k P a})$ & Tests A & Tests B & {$[\mathbf{3 - 4}]$} \\
\hline 100 & -14.88 & -2.58 & 20 \\
\hline 200 & -0.99 & -10.11 & -2.42 \\
\hline 300 & -15.45 & -19.74 & 5.08 \\
\hline 400 & -20.18 & -18.10 & 36 \\
\hline
\end{tabular}




\section{CONCLUSIONS}

The elastic and deformation characteristics for road construction of MSWI bottom ash were studied in this paper. These characteristics were compared to those of construction materials and of other bottom ash reports. One prediction of Young's modulus of bottom ash was analyzed. The main conclusions of this study are:

- The triaxial tests curves showed that the mechanical behavior of bottom ash is similar to that of dense sand.

- The basic parameters of bottom ash are close to those of sand and gravel, which are typical materials used for construction embankments, road bases, and sub-bases.

- The obtained values of secant moduli indicate that bottom ash exhibits good resistance capacity to deformation.

- The formula of Schanz and Vermeer [20] was simulated to predict secant modulus $E_{50}$ of bottom ash. Moreover the error was relatively high, showing that this formula is not applicable for bottom ash.

\section{REFERENCES}

[1] ADEME and BRGM, Mâchefers d'incinérations des ordures ménagères - États de l'art et perspectives: États de l'art et perspectives. Paris: DUNOD, 2008.

[2] ITOM: Les installations de traitement des ordures. Angers, France: ADEME, 2010.

[3] F. Becquart, "Comportement mécanique au triaxial d'un mâchefer d'incinération d'ordures ménagères," European Journal of Environmental and Civil Engineering, vol. 12, no. 6, pp. 673-686, Jun. 2008, https://doi.org/10.1080/19648189.2008.9693038.

[4] F. Becquart, F. Bernard, N. E. Abriak, and R. Zentar, "Monotonic aspects of the mechanical behaviour of bottom ash from municipal solid waste incineration and its potential use for road construction," Waste Management, vol. 29, no. 4, pp. 1320-1329, Apr. 2009, https://doi.org/ 10.1016/j.wasman.2008.08.019.

[5] N. Bheel, M. A. Jokhio, J. A. Abbasi, H. B. Lashari, M. I. Qureshi, and A. S. Qureshi, "Rice Husk Ash and Fly Ash Effects on the Mechanical Properties of Concrete," Engineering, Technology \& Applied Science Research, vol. 10, no. 2, pp. 5402-5405, Apr. 2020, https://doi.org/ 10.48084/etasr.3363.

[6] M. Izquierdo, E. Vazquez, X. Querol, M. Barra, A. Lopez, and F. Plana, "Use of bottom ash from municipal solid waste incineration as a road material," presented at the 2001 International Ash Utilization Symposium, Center for Applied Energy Research, Kentucky, KY, 2001, Art. No. 37.

[7] N. Radwan and S. A. Mangi, "Municipal Solid Waste Management Practices and Opportunities in Saudi Arabia," Engineering, Technology \& Applied Science Research, vol. 9, no. 4, pp. 4516-4519, Aug. 2019, https://doi.org/10.48084/etasr.2870.

[8] H. Maniam, S. Nagapan, A. H. Abdullah, S. Subramaniam, and S. Sohu, "A Comparative Study of Construction Waste Generation Rate Based on Different Construction Methods on Construction Project in Malaysia," Engineering, Technology \& Applied Science Research, vol. 8, no. 5, pp. 3488-3491, Oct. 2018, https://doi.org/10.48084/etasr.2340.

[9] S. Nagapan et al., "Preliminary Survey on the Crucial Root Causes of Material Waste Generation in Malaysian Construction Industry," Engineering, Technology \& Applied Science Research, vol. 8, no. 6, pp. 3580-3584, Dec. 2018, https://doi.org/10.48084/etasr.2388.

[10] B. R. Broujeni, G. A. Omrani, R. Naghavi, and S. S. Afraseyabi, "Construction and Demolition Waste Management (Tehran Case Study)," Engineering, Technology \& Applied Science Research, vol. 6, no. 6, pp. 1249-1252, Dec. 2016, https://doi.org/10.48084/etasr.812.
[11] S. A. Chandio, B. A. Memon, M. Oad, F. A. Chandio, and M. U. Memon, "Effect of Fly Ash on the Compressive Strength of Green Concrete," Engineering, Technology \& Applied Science Research, vol. 10, no. 3, pp. 5728-5731, Jun. 2020, https://doi.org/10.48084/etasr.3499.

[12] R. Forteza, M. Far, C. Seguí, and V. Cerdá, "Characterization of bottom ash in municipal solid waste incinerators for its use in road base," Waste Management, vol. 24, no. 9, pp. 899-909, Jan. 2004, https://doi.org/ 10.1016/j.wasman.2004.07.004.

[13] M. Izquierdo, Á. López-Soler, E. V. Ramonich, M. Barra, and X. Querol, "Characterisation of bottom ash from municipal solid waste incineration in Catalonia," Journal of Chemical Technology \& Biotechnology, vol. 77, no. 5, pp. 576-583, 2002, doi: 10.1002/jctb.605.

[14] M.-C. Weng, C.-L. Lin, and C.-I. Ho, "Mechanical properties of incineration bottom ash: The influence of composite species," Waste Management, vol. 30, no. 7, pp. 1303-1309, Jul. 2010, https://doi.org/ 10.1016/j.wasman.2009.11.010.

[15] F. Becquart, "Comportement mécanique au triaxial d'un mâchefer d'incinération d'ordures ménagères," European Journal of Environmental and Civil Engineering, vol. 12, no. 6, pp. 673-686, Jun. 2008, https://doi.org/10.1080/19648189.2008.9693038.

[16] N. Le, N. E. Abriak, C. Binetruy, M. Benzerzour, and S. Chaki, "The study of behavior of bottom ash under homogeneous stresses. Determination of parameters for Nova behavior models," presented at the Euromediterranean Symposium on Advances in Geomaterials and Structures, Djerba, Tunisia.

[17] Acceptabilité environnementale de matériaux alternatifs en technique routière: Les mâchefers d'incinération de déchets non dangereux. Paris, France: Setra, 2012.

[18] Réalisation des remblais et des couches de forme: Fascicule I: Principes generaux, 2nd ed. Paris, France: Setra, 2000.

[19] N. Lapa, R. Barbosa, J. Morais, B. Mendes, J. Méhu, and J. F. Santos Oliveira, "Ecotoxicological assessment of leachates from MSWI bottom ashes," Waste Management, vol. 22, no. 6, pp. 583-593, Oct. 2002, https://doi.org/10.1016/S0956-053X(02)00009-0.

[20] T. Schanz and P. A. Vermeer, "Angles of friction and dilatancy of sand," Géotechnique, vol. 46, no. 1, pp. 145-151, Mar. 1996, https://doi.org/10.1680/geot.1996.46.1.145.

[21] EN 13286-2:2004. Unbound and hydraulically bound mixtures - Part 2: Test methods for the determination of the laboratory reference density and water content - Proctor compaction. CEN, 2004.

[22] D. M. Wood, Soil Behaviour and Critical State Soil Mechanics. Cambridge, UK: Cambridge University Press, 1990.

[23] T. W. Lambe and R. V. Whitman, Soil Mechanics. Hoboken, NJ, USA: John Wiley \& Sons, 1991.

[24] T. L. Nguyen, "Etude expérimentale de la loi d'écoulement de matériaux anisotropes tranverses," Ph.D. dissertation, École Nationale des Ponts et Chaussées, 2008.

[25] B. M. Das and K. Sobhan, Principles of Geotechnical Engineering, 8th ed. Cengage Learning, 2012.

[26] M. R. B. Cox, "The Influence of Grain Shape on Dilatancy," Ph.D. dissertation, University of Arizona, Tucson, AZ, 2008.

[27] G. Ranjan and A. S. R. Rao, Basic and Applied Soil Mechanics, 2nd ed. New Delhi, India: New Age International, 2000. 